\title{
ENSURING FOOD SECURITY IN THE CONTEXT OF THE SUSTAINABLE DEVELOPMENT OF AGRICULTURE
}

\author{
Anna Burkovska1, Olena Shebanina ${ }^{2}$, Tetyana Lunkina ${ }^{3}$, Alla Burkovska ${ }^{4}$ \\ ${ }^{I}$ Assistant, Mykolayiv National Agrarian University, Georgiy Gongadze str. 3a, 54020 Mykolayiv, Ukraine. \\ Phone No. +380974828736, E-mail address: anna.burkovskaya12@gmail.com \\ ${ }^{2}$ Doctor of Economics, Professor, Mykolayiv National Agrarian University. \\ Phone No.+380504932907,E-mail address: shebanina@mnau.edu.ua \\ ${ }^{3}$ Doctor of Economics, Assoc. Prof., Mykolayiv National Agrarian University. \\ Phone No.+380679636126, E-mail address: lunkina_tanya@i.ua \\ ${ }^{4}$ Assoc. Prof., Mykolayiv National Agrarian University, Georgiy. \\ Phone No.+380973841769, E-mail address: allaburkovska2010@gmail.com
}

Received 0604 2021; Accepted 13042021

\begin{abstract}
Food security is a fundamental basis for social stability and development of all countries. The task of ensuring and maintaining food security is included into the list of the sustainable development goals (SDGs) of the United Nations. At the same time, the formation of food security requires effective actions that must take into account the principles of sustainable development in order to preserve biological diversity, ecological stability and prevent negative impacts on the environment. The purpose of this article is to analyze the impact of factors that shape food security on the environmental component of sustainable development. The study is based on data of the World Bank and regional statistical agencies, including selected factors that have a significant impact on the environmental component of sustainable development in the context of food security. The research methodology includes correlation analysis of the impact of a group of factors that ensure food security on the environment of the regions; assessment of the significance of factors and the reliability of the model. The key results of the study confirm the hypothesis of the impact of anthropogenic factors on the ecological balance of the environment, which allows focusing on approaches to the choice of agricultural production technology, based on the experience of both large agricultural holdings and family farms in Ukraine and Italy.
\end{abstract}

Keywords: bio-production, correlation-regression analysis, ecology, food security, social policy, social stability, sustainable development.

JEL Codes: $Q 12, Q 14$.

\section{Introduction}

The dilemma of choosing between agrifood production greening and providing enough food has always been problematic in the process of food security research. Thus, according to Kotykova O., and Albeshchenko O. (2017) the country's food security should be based primarily on the adequacy of the physical mass of food to maintain a balanced diet of the world's population. At the same time, studies by Cordell D., Turner A., and Chong J. (2015) emphasize the importance of the environmental component of agricultural production to maintain food security. The question of finding a balance between quantitative and qualitative indicators of food production forms a scientific problem, the relevance of which is to bring modern agrifood production to sustainable principles aimed at preserving the environment.

Implementation of tasks for the development of the agricultural sector as a basis for stable functioning and economic

Copyright (C) 2021 Author(s), published by Vytautas Magnus University. This is an open access article distributed under the terms of the Creative Commons Attribution Non-Commercial 4.0 (CC BY-NC 4.0) license, which permits unrestricted use, distribution, and reproduction in any medium provided the original author and source are credited. The material cannot be used for commercial purposes 
security of the national economy requires the introduction of effective tools to improve the efficiency of resource potential in agriculture, improving the sectoral structure with a focus on implementing a complete cycle of food production, economic and social efficiency functioning of economic entities, taking into account their contribution to the development of rural areas and rational use of nature. At the present stage of socio-economic transformations, this highlights the need to improve existing theoretical and methodological developments in the formation and implementation of state agricultural policy, as well as justification of new applied management decisions, taking into account their contribution to the agricultural sector and economic security.

The research methodology of this paper includes a correlation analysis of the impact of a group of factors that ensure food security on the environment of the regions; assessment of the significance of factors and the reliability of the model. The following methods were also used during the research: monographic - for the study and theoretical generalization of modern scientific research on food security; comparative analysis - to compare the actual data of factors influencing the state of food security; tabular - for a visual representation of the dynamics of indicators; statistical - to analyze the impact of individual factors on the resulting indicator. The study covers the period from 2010 to 2018. To analyze the array of information, a correlation matrix was constructed using the tools of statistical data analysis software JASP. The key results of the study confirm the hypothesis of the impact of anthropogenic factors on the ecological balance of the environment, which allows focusing on approaches to the choice of agricultural production technology, based on the experience of both large agricultural holdings and family farms in Ukraine and Italy. The choice of countries for the study is due to the logic of continuing the research started in 2019 at the University of Politecnico di Milano, the preliminary results of which were published in the article by Burkovska, A.,
Ciccullo, F., Shebanina, O. and Lunkina, T. (2019).

State regulation of agriculture is a priority for European countries, because the efficiency of the food sector is a constant prerequisite for the prosperity of society as a whole. Within the framework of state regulation, various tasks are solved: support of prices and incomes of agricultural producers, purposeful formation of appropriate conditions of sale and production, resource conservation, environmental protection, social support of producers and infrastructure policy for rural areas.

Current trends and problematic aspects of the economy, in particular its agricultural component, require the development of new approaches to identifying priority areas and ways to fulfill the resource and economic potential of the agricultural sector, the formation of institutional support for its sustainable development and economic security.

\section{Literature analysis}

The critical review of the agri-food supply chain evolution, which implied life cycle assessment, environmental impact, food waste prevention as well as carbon footprint issues, was carried out by Barbosa M. (2021). The main indicators of food security as well as the methodology of their calculation were studied by Babych M. and Kovalenko A. (2018). The overall research of the environmental sustainability as an integrated component of national food policy was performed by Brown K., Venkateshmurthy N., Law C., Harris F., Suneetha K., Shankar B., Mohan S., Prabhakaran, D. and Knai C. (2021). A cross-project dataset to analyze the overall effect of different agricultural interventions on food security was constructed by Garbero A. and Jackering L. (2021).

The solutions to the problem of an appropriate nutrition in the modern world in terms of sustainability and global climate change fight were considered by Cheeseman J. (2016). The consequences and potential risks of inappropriate phosphorus use in agriculture are analyzed by Cordell D., Turner 
A. and Chong J. (2015). The link between climate change and food security in relation to impacts on crop production or food availability aspects of food security was explored by Esham M., Jacobs B., Rosairo H. and Siddighi B. (2018). The monitoring and evaluation of agricultural land use sustainability in the post-socialist camp countries were carried out by Kotykova O., Kuzmenko O. and Semenchuk I. (2019). The valuation by measuring metric indices of sustainable development in the space of three pillars (economic, environmental and social) in the context of quality and safety of life is performed by Kotykova O., and Albeshchenko O. (2017).

The nutritional and environmental impacts of global food systems were examined and the apparent decrease in food sources and crop diversity was addressed by Maysou A., Tafadzwanashe M. and Festo M. (2021). The using of Theory of Change approach with strong emphasis on communication and stakeholder engagement was argued by Rajala E., Vogel I., Sundin A., Kongmanila D., Nassuna-Musoke M., Musundire R., Mulangala M., ChiwinaKarltun L., Magnusson U. and Boqvist S. (2021). The correlation between the economic affordability of food and the average monthly wage in the country is formulated in terms of food security regulation by Shebanina O., Klyuchnik A., Burkovska A. and Caruso, D. (2018). The science-policy interface as boundary networks between researches and policy-makers to generate policies that are better-informed and better tailored to small farms` situation was explored by Sumane S., Dionisio M., Pinto-Correia T., Czekai M., Duckett D., Galli F., Grivins M., Noble C., Tisenkopfs T., Toma I. and Tsiligiridis T. (2021).

\section{Aims of the article}

The purpose of this article is to analyze the impact of factors that shape food security on the environmental component of sustainable development. The study is based on data of the World Bank and regional statistical agencies, including selected factors that have a significant impact on the environmental component of sustainable development in the context of food security.

The object of research is ensuring a sustainable approach to the formation of food security. The subject of the study is the relationship of the system of indicators, including environmental pollution by methane emissions from agriculture; the amount of fertilizers applied per hectare; the share of organic production in the overall structure of land use; the share of land provided with an irrigation system; government spending on agricultural development and crop productivity.

The research methodology includes a correlation analysis of the impact of a group of factors that ensure food security on the environment of the regions; assessment of the significance of factors and the reliability of the model. The study covers the period from 2010 to 2018. To analyze the array of information, a correlation matrix was constructed using the tools of statistical data analysis software JASP. The key results of the study confirm the hypothesis of the impact of anthropogenic factors on the ecological balance of the environment, which allows focusing on approaches to the choice of agricultural production technology, based on the experience of both large agricultural holdings and family farms in Ukraine and Italy. The choice of countries for the study is due to the logic of continuing the research started in 2019 at the University of Politecnico di Milano, the preliminary results of which were published in the article by Burkovska, A., Ciccullo, F., Shebanina, O. and Lunkina, T. (2019).

\section{Results and discussion}

Food security is based not only on the adequacy of food to meet the needs of the population, but also on the affordability of food, ease of food distribution and environmental safety. At the same time, there 
have been recent contradictions between some components of food security. Thus, the affordability of food often leads to lower product quality and the use of agronomic technologies that do not meet the principles of sustainable development.

The task of harmoniously combining all components of food security in order to ensure comprehensive protection of the wellbeing of the population and strengthen the economic stability of the regions requires detailed study. Thus, in order to find correlation between food security and sustainable development of society, we analyzed a system of indicators in the dynamics, including environmental pollution by methane emissions from agriculture; the amount of fertilizers applied per hectare; the share of organic production in the overall structure of land use; the share of land provided with an irrigation system; government spending on agricultural development and crop productivity (tables 1 ,
2). As can be seen from Table 1, during the study period, grain yields had a steady upward trend in Ukraine. At the same time, there was a sharp reduction in methane emissions in the agricultural sector, a reduction in government spending on the agricultural sector, a reduction in the share of land with irrigation systems, an increase in the share of land used in organic production and an increase in fertilizers per hectare. Thus, the analyzed data show positive trends in reducing the negative environmental impact of agriculture while increasing yields, which is an important factor in ensuring food security. The reduction of methane emissions in recent years is explained by the modernization of production at many agricultural enterprises, the transition to technologies that cause less damage to the environment, the reduction of livestock and the predominant use of organic fertilizers in households.

Table 1. The system of model indicators, Ukraine

\begin{tabular}{|c|c|c|c|c|c|c|}
\hline $\begin{array}{c}\text { Time } \\
\text { period }\end{array}$ & $\begin{array}{c}\text { Cereal } \\
\text { yield } \\
\text { (tones } \\
\text { per } \\
\text { hectare) }\end{array}$ & $\begin{array}{c}\text { Agricultural } \\
\text { methane emissions } \\
\text { (thousand metric } \\
\text { tons of CO2 } \\
\text { equivalent) }\end{array}$ & $\begin{array}{c}\text { Percentage of } \\
\text { utilized } \\
\text { agricultural area } \\
\text { under organic } \\
\text { farming, \% }\end{array}$ & $\begin{array}{c}\text { Fertilizers } \\
\text { distributed in } \\
\text { agriculture, } \\
\text { kg per ha }\end{array}$ & $\begin{array}{c}\text { Share of } \\
\text { public } \\
\text { expenditure on } \\
\text { agriculture, \% }\end{array}$ & $\begin{array}{c}\text { Agricultural } \\
\text { irrigated land } \\
\text { (\% of total } \\
\text { agricultural } \\
\text { land) }\end{array}$ \\
\hline $\mathbf{2 0 1 0}$ & 2.726 & 19275 & 0.0083 & 60 & 1.3 & 0.897 \\
\hline $\mathbf{2 0 1 1}$ & 3.753 & 19827 & 0.0084 & 72 & 1.8 & 0.899 \\
\hline $\mathbf{2 0 1 2}$ & 3.156 & 19538 & 0.0086 & 79 & 1.3 & 0.91 \\
\hline $\mathbf{2 0 1 3}$ & 4.030 & 17528 & 0.0122 & 87 & 1.4 & 0.968 \\
\hline $\mathbf{2 0 1 4}$ & 4.400 & 16413 & 0.0123 & 93 & 0.9 & 0.747 \\
\hline $\mathbf{2 0 1 5}$ & 4.140 & 14449 & 0.0126 & 98 & 0.3 & 0.756 \\
\hline $\mathbf{2 0 1 6}$ & 4.651 & 12313 & 0.0117 & 110 & 0.26 & 0.792 \\
\hline $\mathbf{2 0 1 7}$ & 4.315 & 10279 & 0.0120 & 123 & 0.31 & 0.784 \\
\hline $\mathbf{2 0 1 8}$ & 4.335 & 10012 & 0.0122 & 134 & 1.18 & 0.759 \\
\hline
\end{tabular}

*Source: composed by author using (World..., 2021), (Sustainable..., 2020), (The total..., 2019)

To build a model of the impact of food security factors on the environmental aspect of sustainable economic development (tables 1 and 2), it is important to study the statistics of changes in environmental and economic indicators in the dynamics. Since the construction of a model of the impact of food security factors on the environmental aspect of sustainable economic development requires a comparison of several regions with different socio-economic preconditions, the data representing not only Ukraine but also Italy were analyzed. At the same time, the statistics of the studied indicators in Italy, which were included in the model of studying the impact of food security factors on the sustainable development of the region's economy, have some differences from the data for Ukraine. 
Thus, in Italy, statistics show that grain yields in the study period did not have a steady trend towards significant changes and remained mostly at a constant level. At the same time, in the period under study there was a clear tendency to reduce methane emissions in the agricultural sector, which can be explained by the modernization of production at many agricultural enterprises, the transition to technologies that cause less damage to the environment and others. During the study period, there was an overall reduction in government spending to support the agricultural sector in the country, but it had an uneven trend. The overall decrease in the share of land with irrigation systems was synchronous with the increase in the share of land used in organic production and the increase in the amount of fertilizers applied per 1 ha.

Based on the analyzed indicators in the dynamics, we can find common and different trends in the scenarios of food security in Ukraine and Italy, given that the agri-food sector occupies an important place in the economies of both countries. Thus, the primary hypothesis on the impact of food security factors on the environmental aspect of sustainable economic development is that the intensification of production through the use of modern tillage technologies, rational fertilization and transition to organic production has a direct impact on reducing methane emissions in agriculture. To verify this hypothesis, we perform calculations, the results of which are shown in tables 3 and 4 .

Table 2. The system of model indicators, Italy

\begin{tabular}{|c|c|c|c|c|c|c|}
\hline $\begin{array}{c}\text { Time } \\
\text { period }\end{array}$ & $\begin{array}{c}\text { Cereal } \\
\text { yield } \\
\text { (tones per } \\
\text { hectare) }\end{array}$ & $\begin{array}{c}\text { Agricultural } \\
\text { methane emissions } \\
\text { (thousand metric } \\
\text { tons of CO2 } \\
\text { equivalent) }\end{array}$ & $\begin{array}{c}\text { Percentage of } \\
\text { utilized } \\
\text { agricultural } \\
\text { area under } \\
\text { organic farming, } \\
\text { \% }\end{array}$ & $\begin{array}{c}\text { Fertilizers } \\
\text { distributed in } \\
\text { agriculture, } \\
\text { kg per ha }\end{array}$ & $\begin{array}{c}\text { Share of } \\
\text { public } \\
\text { expenditure on } \\
\text { agriculture, \% }\end{array}$ & $\begin{array}{c}\text { Agricultural } \\
\text { irrigated land } \\
\text { (\%) of total } \\
\text { agricultural } \\
\text { land) }\end{array}$ \\
\hline $\mathbf{2 0 1 0}$ & 5.322 & 17157 & 8.7 & 497.7 & 0.69 & 16.827 \\
\hline $\mathbf{2 0 1 1}$ & 5.677 & 16912 & 8.5 & 550.9 & 0.74 & 17.123 \\
\hline $\mathbf{2 0 1 2}$ & 5.315 & 16800 & 9.1 & 532.0 & 0.56 & 18.05 \\
\hline $\mathbf{2 0 1 3}$ & 5.264 & 16465 & 10.6 & 474.0 & 0.51 & 19.083 \\
\hline $\mathbf{2 0 1 4}$ & 5.709 & 16249 & 11.2 & 487.1 & 0.54 & 18.987 \\
\hline $\mathbf{2 0 1 5}$ & 5.384 & 15872 & 12.0 & 466.2 & 0.45 & 18.612 \\
\hline $\mathbf{2 0 1 6}$ & 5.602 & 15809 & 14.3 & 490.7 & 0.42 & 19.023 \\
\hline $\mathbf{2 0 1 7}$ & 5.171 & 15593 & 15.2 & 525.6 & 0.41 & 19.145 \\
\hline $\mathbf{2 0 1 8}$ & 5.210 & 15320 & 15.5 & 509.8 & 0.42 & 18.712 \\
\hline
\end{tabular}

*Source: composed by author using (World..., 2021), (Sustainable..., 2020), (The total..., 2019)

The following indicators were used to build a model of the impact of food security factors on the environmental aspect of sustainable economic development: agricultural methane emissions (dependent variable), cereal yield, fertilizers distributed in agriculture, agricultural irrigated land, share of public expenditure on agriculture, percentage of utilized agricultural area under organic farming (independent variables).
The constructed correlation matrix demonstrates the relationship between the factors of the model with the assessment of its significance. Thus, in the model of studying the impact of food security factors on the environmental aspect of sustainable development of Ukraine's economy there is a strong correlation between the dependent variable and the amount of fertilizers $(-0.963$, p-value <.001), crop productivity $(-0.736, \mathrm{p}-$ 
value <.024) and the share of land use for organic production $(-0.732$, p-value <.025). There is also a strong direct relationship between the dependent variable and irrigation use indicators $(0.730, \mathrm{p}$-value <.025) and the cost of supporting agricultural programs (0.694, p-value <.038).

In addition, according to the analysis, the change in crop productivity has a strong direct correlation with the use of agricultural land for organic production $(0.844$, p-value $<.004)$ and the amount of fertilizers $(0.782, \mathrm{p}-$ value <.013). At the same time, the amount of fertilizers applied in agricultural production has a strong direct correlation with the share of land used for organic land use $(0.748$, pvalue <.021), as well as an inverse relationship with the use of irrigation systems in the fields, p-value <.041). At the same time, the use of irrigation systems in the fields demonstrates a direct relationship with the amount of costs to support agricultural programs $(0.702$, p-value <.035).

Table 3. Person correlations of the researched factors (between food security and sustainable development of society factors), Ukraine

\begin{tabular}{|c|c|c|c|c|c|c|c|c|c|}
\hline \multirow{3}{*}{$\begin{array}{l}\text { Agricultural } \\
\text { methane emissions }\end{array}$} & \multirow{3}{*}{$\begin{array}{l}\text { Pearson's r } \\
\text { p-value }\end{array}$} & \multicolumn{2}{|l|}{$\begin{array}{c}\text { Agricultural } \\
\text { methane } \\
\text { emissions }\end{array}$} & \multirow[t]{2}{*}{$\begin{array}{l}\text { Cereal } \\
\text { yield }\end{array}$} & \multicolumn{2}{|c|}{$\begin{array}{c}\text { Fertilizers } \\
\text { distributed in } \\
\text { agriculture } \\
\end{array}$} & \multicolumn{2}{|c|}{$\begin{array}{l}\text { Agricultural } \\
\text { irrigated land }\end{array}$} & $\begin{array}{c}\text { Share of public } \\
\text { expenditure on } \\
\text { agriculture }\end{array}$ \\
\hline & & - & & & & & & & \\
\hline & & - & & & & & & & \\
\hline \multirow{2}{*}{ Cereal yield } & Pearson's r & -0.736 & $*$ & - & & & & & \\
\hline & p-value & 0.024 & & - & & & & & \\
\hline \multirow{2}{*}{$\begin{array}{l}\text { Fertilizers } \\
\text { distributed in } \\
\text { agriculture }\end{array}$} & Pearson's $r$ & -0.963 & $* * *$ & 0.782 & $*$ & - & & & \\
\hline & p-value & $<.001$ & & 0.013 & & - & & & \\
\hline \multirow{2}{*}{$\begin{array}{l}\text { Agricultural } \\
\text { irrigated land }\end{array}$} & Pearson's r & 0.730 & $*$ & -0.643 & & -0.688 & $*$ & - & \\
\hline & $\mathrm{p}$-value & 0.025 & & 0.062 & & 0.041 & & - & \\
\hline \multirow{2}{*}{$\begin{array}{l}\text { Share of public } \\
\text { expenditure on } \\
\text { agriculture }\end{array}$} & Pearson's r & 0.694 & $*$ & -0.568 & & -0.575 & & 0.702 & - \\
\hline & $\mathrm{p}$-value & 0.038 & & 0.111 & & 0.105 & & 0.035 & - \\
\hline $\begin{array}{l}\text { Percentage of } \\
\text { utilized agricultural }\end{array}$ & Pearson's $\mathrm{r}$ & -0.732 & $*$ & 0.844 & $* *$ & 0.748 & $*$ & -0.612 & -0.636 \\
\hline $\begin{array}{l}\text { area under organic } \\
\text { farming }\end{array}$ & p-value & 0.025 & & 0.004 & & 0.021 & & 0.080 & 0.065 \\
\hline
\end{tabular}

$* \mathrm{p}<.05, * * \mathrm{p}<.01, * * * \mathrm{p}<.001$

*Source: composed by author using JASP

The obtained results confirm the previously formed hypothesis of the study, but require additional interpretation. Thus, the intensification of production through the use of modern tillage technologies, rational application of fertilizers and the transition to organic production have a direct impact on reducing methane emissions in the agricultural sector of Ukraine. At the same time, the use of outdated irrigation systems and the expansion of agricultural production are directly correlated with an increase in methane emissions in the agri-food sector. 
Table 4. Person correlations of the researched factors (between food security and sustainable development of society factors), Italy

\begin{tabular}{|c|c|c|c|c|c|c|c|c|c|}
\hline & & $\begin{array}{r}\text { Agricul } \\
\text { meth: } \\
\text { emissi }\end{array}$ & & $\begin{array}{c}\text { Cereal } \\
\text { yield }\end{array}$ & $\begin{array}{c}\text { Fertilizers } \\
\text { distributed in } \\
\text { agriculture }\end{array}$ & $\begin{array}{l}\text { Agricult } \\
\text { irrigated }\end{array}$ & $\begin{array}{l}\text { ral } \\
\text { and }\end{array}$ & $\begin{array}{r}\text { Share o } \\
\text { expendi } \\
\text { agricu }\end{array}$ & $\begin{array}{l}\text { blic } \\
\text { on } \\
\text { e }\end{array}$ \\
\hline Agricultural methane & Pearson's r & - & & & & & & & \\
\hline emissions & $\mathrm{p}$-value & - & & & & & & & \\
\hline Coreol viold & Pearson's r & 0.270 & & 一 & & & & & \\
\hline Cereal yield & p-value & 0.482 & & - & & & & & \\
\hline Fertilizers distributed in & Pearson's r & 0.244 & & 0.040 & - & & & & \\
\hline agriculture & $\mathrm{p}$-value & 0.528 & & 0.918 & - & & & & \\
\hline Agricultural irrigated & Pearson's r & -0.775 & $*$ & -0.154 & -0.451 & - & & & \\
\hline land & $\mathrm{p}$-value & 0.014 & & 0.692 & 0.224 & - & & & \\
\hline Share of public & Pearson's r & 0.906 & $* * *$ & 0.389 & 0.420 & -0.887 & $* *$ & - & \\
\hline $\begin{array}{l}\text { expenditure on } \\
\text { agriculture }\end{array}$ & p-value & $<.001$ & & 0.300 & 0.261 & 0.001 & & - & \\
\hline Percentage of utilized & Pearson's r & -0.967 & $* * *$ & -0.319 & -0.179 & 0.732 & $*$ & -0.888 & $* *$ \\
\hline $\begin{array}{l}\text { agricultural area under } \\
\text { organic farming }\end{array}$ & p-value & $<.001$ & & 0.403 & 0.646 & 0.025 & & 0.001 & \\
\hline
\end{tabular}

$* \mathrm{p}<.05, * * \mathrm{p}<.01, * * * \mathrm{p}<.001$

*Source: composed by author using JASP

In the model of studying the impact of food security factors on the environmental aspect of sustainable development of the Italian economy there is a strong direct relationship between the dependent variable and the share of land used for organic land use (-0.967, p-value <.001) and the share of land with established irrigation systems in the general structure of agricultural land use (0.775 , p-value <.014). There is also a strong direct relationship between the dependent variable and the amount of public spending on agricultural programs support $(0.906, \mathrm{p}$-value $<.001)$.

In addition, according to the analysis, the change in the share of land with established irrigation systems in the overall structure of agricultural land use of crops has a strong direct correlation with the use of agricultural land for organic production (0.732, p-value <.025) and inverse relationship with the amount of public spending in support of agricultural programs $(-0.887$, p-value <.001), which is due to the predominant funding for the replacement and upgrade of existing irrigation systems. At the same time, the amount of public spending to support agricultural programs has a strong inverse correlation with the share of land used for organic land use $(-0.888$, p-value <.001), due to less need for financial resources for the use of modern organic farming technologies in comparison with classical methods of agrofood production.

The obtained results confirm the previously formed hypothesis of the study, but require additional interpretation. Thus, the intensification of production through the use of modern tillage technologies, modernization and renewal of irrigation systems, and the transition to organic production have a direct impact on reducing methane emissions in agriculture in Italy, while expanding agricultural production is directly correlated with increasing methane emissions in agrifood.

\section{Conclusions}

Food security is based not only on the sufficiency of food to meet the needs of the population, but also on the affordability of food, ease of distribution and environmental safety. At the same time, there have been 
recent contradictions between some components of food security. Thus, the affordability of food often leads to lower product quality and the use of agronomic technologies that do not meet the principles of sustainable development.

In order to find the correlation between food security and sustainable development of society, we analyzed the system of indicators in the dynamics, including environmental pollution by methane emissions from agriculture; the amount of fertilizers applied per hectare; the share of organic production in the overall structure of land use; the share of land provided with an irrigation system; government spending on agricultural development and crop productivity. The primary hypothesis about the impact of food security factors on the environmental aspect of sustainable economic development was that the intensification of production through the use of modern tillage technologies, rational application of fertilizers and the transition to organic production have a direct impact on reducing methane emissions in agriculture.

The obtained results confirm the previously formed hypothesis of the study. Thus, the intensification of production through the use of modern tillage technologies, rational application of fertilizers and the transition to organic production have a direct impact on reducing methane emissions in the agricultural sector of Ukraine. At the same time, the use of outdated irrigation systems and the expansion of agricultural production are directly correlated with increased methane emissions in the agri-food sector. At the same time, the intensification of production through the use of upgraded irrigation systems and the transition to organic production have a direct impact on reducing methane emissions in agriculture in Italy, while the expansion of agricultural production is directly correlated with increasing methane emissions in agrifood.

The analysis of variables of the model of influence of the factors providing productivity of agricultural production on the volume of methane emissions that characterizes the level of environmental friendliness of agricultural technologies is carried out. This allows us to conclude about the dualism of food security: on the one hand, it is necessary to increase the productivity of food production, on the other hand, the environmental component of food security remains important. According to the study of the built model, anthropogenic interference in the food production process increases methane emissions, which worsens the environmental condition. Thus, the stated problem of harmonization of increase of production volumes with observance of steady approaches acquires special urgency. The authors see the solution to this problem in the following: 1) strengthening state support for the development of sustainable technologies of agricultural production; 2) minimization of food costs and development of waste recycling technologies; 3) modernization of productive forces and cooperation of production facilities in order to increase the technological potential of individual producers.

\section{References}

Babych, M. and Kovalenko, A. (2018). Food Security Indicators in Ukraine: Current State and Trends of Development // Baltic Journal of Economic Studies. Vol.4. No. 1, p. 8-15. https://doi.org/10.30525/2256-0742/2018-41-8-15

Barbosa, M. (2021). Uncovering research streams on agri-food supply chain management: A bibliometric study // Global Food Security. Vol. 28, p. 105-116. https://doi.org/10.1016/j.gfs.2021.100517

Brown, K., Venkateshmurthy, N., Law, C., Harris, F., Suneetha, K., Shankar, B., Mohan, S., Prabhakaran, D., and Knai, C. (2021). Moving towards sustainable food systems: A review of Indian food policy budgets // Global Food Security. Vol. 28, p. 345-356. https://doi.org/10.1016/j.gfs.2020.100462

Burkovska, A., Ciccullo, F., Shebanina, O. and Lunkina, T. (2019). Modeling the System of Social Stability Through the Food Safety Paradigm// Management Theory and Studies for Rural Business and Infrastructure Development. Vol.41. No. 4, p. 474-486. https://doi.org/10.15544/mts.2019.38 


\title{
Sciendo
}

\author{
Management Theory and Studies for Rural Business and Infrastructure Development \\ eISSN 2345-0355. 2021. Vol. 43. No. 3: 337-345 \\ Article DOI: https://doi.org/10.15544/mts.2021.30
}

Garbero, A. and Jackering, L. (2021). The potential of agricultural programs for improving food security: A multy-country perspective // Global Food Security. Vol. 29, p. 127-135. https://doi.org/10.1016/j.gfs.2021.100529

Cheeseman, J. (2016). Food Security in the Face of Salinity, Draught, Climate Changeand Population Growth // Halophytes for Food Security in Dry Lands. Vol. 23, p. 111-123. https://doi.org/10.1016/B978-0-12-801854-5.00007-8

Cordell, D., Turner, A., and Chong, J. (2015). The hidden cost of phosphate: Mapping the sustainability impacts and risks of phosphate fertilisers along the supply chain from extraction to the dinner table, Global Change. Peace and Security, 27(3), 323-343. https://doi.org/10.1080/14781158.2015.1083540

Esham, M., Jacobs, B., Rosairo, H., and Siddighi, B. (2018). Climate change and food security: A Sri Lankan $\begin{array}{llll}\text { perspective. Environment, Development and } & \text { Sustainability, } 20(3), & \text { 1017-1036. }\end{array}$ https://link.springer.com/article/10.1007/s10668-017-9945-5

Kotykova, O., Kuzmenko, O. and Semenchuk, I. (2019). Sustainable agricultural land use in the post-socialist camp countries: monitoring and evaluation // Baltic journal of economic studies. Vol. 5, No. 1, p. 101-111. https://doi.org/10.30525/2256-0742/2019-5-1-101-111

Kotykova, O., and Albeshchenko, O. (2017). An indication of the sustainable development of Ukraine in global Dimentsions // Baltic journal of economic studies. Vol. 3, No. 5, p. 196-202. http://dx.doi.org/10.30525/22560742/2017-3-5-196-202

Maysou, A., Tafadzwanashe, M., and Festo, M. (2021). Building a resilient and Sustainable food system in a changing world - A case for climate-smart and nutrient dense crops // Global Food Security. Vol. 28, p. 195-207. https://doi.org/10.1016/j.gfs.2020.100477

Rajala, E., Vogel, I., Sundin, A., Kongmanila, D., Nassuna-Musoke,M., Musundire, R., Mulangala, M., Chiwina-Karltun, L., Magnusson, U., and Boqvist, S. (2021). How can agricultural research translation projects targeting smallholder production systems be strengthened by using Theory of Change? // Global Food Security. Vol. 28, p. 212-225. https://doi.org/10.1016/j.gfs.2020.100475

Shebanina, O., Klyuchnik, A., Burkovska, A. and Caruso, D. (2018). Providing Labour Income as a Supporting Factor of the Food Security // Management Theory and Studies for Rural Business and Infrastructure Development. Vol. 40, p. 597-608. https://doi.org/10.15544/mts.2018.52

Sumane, S., Dionisio, M., Pinto-Correia,T., Czekai, M., Duckett, D., Galli, F., Grivins, M., Noble, C., Tisenkopfs, T., Toma, I. and Tsiligiridis, T. (2021). Supporting the role of small farms in the European regional food systems: What role for the science-policy interface? // Global Food Security. Vol. 28, p. 319-327. https://doi.org/10.1016/j.gfs.2020.100433

Sustainable Development Goals of the 2030 Agenda. Italian data for UN-SDGs. (2020). Retrieved from https://www.istat.it/storage/SDGs/SDG_15_Italy.pdf [2021 01 03].

The total area of organic farming. Organic in Ukraine. (2019). Retrieved from http://organic.com.ua/en/organicin-ukraine/ [ $\left.\begin{array}{llll}2021 & 01 & 03\end{array}\right]$.

World Bank Open Data. (2021). Retrieved from https://data.worldbank.org/ [2021 03 03]. 